\title{
Relationship between Vitamin D Level on Pain, Functional Status and Quality of Life in Individuals with Osteoarthritis
}

\section{Osteoartritli Bireylerde Vitamin D Düzeyi ile Ağrı, Fonksiyonel Durum ve Yaşam Kalitesi Arasındaki İlişki}

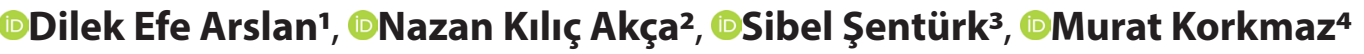 \\ 'University Of Erciyes, Halil Bayraktar Health Services Vocational College, Kayseri, Turkey \\ 2University of Bakırçay, Faculty of Health Sciences, İzmir Turkey \\ ${ }^{3}$ Department of Nursing, Bucak Health School, Burdur Mehmet Akif Ersoy University, Burdur, Turkey \\ ${ }^{4}$ Yozgat Bozok University, Faculty of Medicine Orthopedics Traumatology Department, Yozgat, Turkey
}

\begin{abstract}
Objective: This study was conducted to determine the correlation between vitamin D level and pain, functional status, and quality of life in individuals with osteoarthritis.

Material and Method: This cross-sectional and descriptive study was completed with 138 individuals. The study was carried out between April 15 and August 30, 2019. The research data were collected using the Identification Form, Visual analogue scale, The Western Ontario and McMaster University Osteoarthritis Index and Short Form-36- Quality of Life scale were used.
\end{abstract}

Results: $64.5 \%$ of the individuals had a vitamin D level of $20 \mathrm{ng} / \mathrm{ml}$ and less. It was determined that there was no significant correlation between individuals' vitamin $D$ levels and age, VAS, WOMAC, and SF-36 subscales ( $p>0.05$ ).

Conclusion: Vitamin D deficiency is very common in individuals with osteoarthritis. No relationship was found between vitamin $D$ levels and pain, functional status and quality life of patients.

Keywords: Osteoarthritis, vitamin D, functional status, quality of life.
Öz

Amaç: Bu çalışma, Osteoartritli bireylerde vitamin D düzeyi ile ağrı, fonksiyonel durum ve yaşam kalitesi arasındaki ilişkiyi belirlemek amacıyla yapıldı.

Gereç ve Yöntem: Kesitsel ve tanımlayıcı tipte olan bu çalışma 138 kişi ile 15 Nisan - 30 Ağustos 2019 tarihleri arasında yapııdı. Veriler, tanımlayıcı bilgi formu, Görsel Kıyaslama Ölçeği, WOMAC Osteoartrit Indeksi ve Kısa Form- 36 yaşam kalitesi ölçeği kullanılarak toplandı.

Bulgular: Bireylerin \% 64.5'nin D vitamini düzeyi $20 \mathrm{ng} / \mathrm{ml}$ ve daha düşüktü. Bireylerin D vitamini düzeyleri ile yaş, Görsel Kıyaslama Ölçeği, WOMAC ve SF-36 alt ölçekleri arasında anlamlı bir ilişki olmadığı belirlendi ( $p>0.05)$.

Sonuç: D vitamini eksikliği osteoatritli bireylerde çok yaygındır. Hastaların D vitamini düzeyleri ile ağrı, fonksiyonel durum ve yaşam kalitesi arasında ilişki bulunmadı.

Anahtar Sözcükler: Osteoartrit, vitamin D, fonksiyonel durum, yaşam kalitesi. 


\section{INTRODUCTION}

Osteoarthritis (OA) is a dynamic process that causes symptoms such as pain, decreased ROM and stiffness due to the breakdown of joint cartilage, progresses with mechanical and biochemical factors. Osteoarthritis is ranked as the $13^{\text {th }}$ highest contributor of 310 diseases to global disability in $2015 .^{[1]}$ Although it is thought that genetic, metabolic, environmental, and biomechanical factors affect the pathogenesis, the pathogenesis of OA is not fully known. While cartilage fibrillation is superficial at the beginning of the disease, later the degeneration progresses to deep layers. ${ }^{[2,3]}$ Osteoarthritis affects all elements of a joint such as the cartilage forming the synovial joint, capsule, subchondral bone, synovial tissue, and muscles; however, primary changes include loss of joint cartilage, reshaping of subchondral bone, and formation of osteophytes. ${ }^{[2]}$ Pain, decreased physical function, stiffness, depression and sleep disturbances experienced by patients with decrease the quality of life. ${ }^{[4]}$ The aim of OA treatment is to protect and improve joint functions by eliminating pain and stiffness, to prevent or recover disability, to preserve and improve muscle strength, to increase quality of life and to prevent treatment complications. Currently, there is no effective treatment for reversing or preventing structural changes developed in OA. ${ }^{[5]}$

Vitamin $D$ is a steroid precursor that is important for bone, which undergoes 2 hydroxylations, the first converting vitamin D to 25 - hydroxyvitamin D (25 $(\mathrm{OH}) \mathrm{D})$, which is an indicator of vitamin D status, and the second to the main active form, 1,25-dihydroxy vitamin D. Vitamin D deficiency (VDD) affects calcium metabolism, , articular cartilage structure, and bone density negatively. ${ }^{[6,7]}$ Vitamin D can prevent OA development and progression by reducing degeneration in cartilage and bone.[8] Moreover, in VDD, proinflammatory cytokines are formed; therefore the severity of pain in the joints and bones may increase and the pain process may change. In addition, many researchers have shown the association between VDD with pain, muscle weakness and deterioration of cognitive function. ${ }^{[7,9]}$ Risk of progression of OA doubled in participants with low levels of vitamin D. ${ }^{[10]} \mathrm{Yu}$ et al. ${ }^{[11]}$ was found that there was low association of VDD with knee cartilage loss as evidenced by JSN (joint space narrowing). However, it showed no direct correlation with radiographic knee OA as assessed by osteophytes on plain radiograph. Thus, the association between the concentration of vitamin D and OA is controversial. ${ }^{[12-14]}$ In addition, there is insufficient study showing the correlation between Vitamin D level and pain, functional status, and quality of life in OA. ${ }^{[6,13,14]}$ In our study, vitamin $D$ levels of patients were evaluated together with their quality of life, functional status and pain. In this respect, it is thought that this study will contribute to the literature.

\section{Research questions}

What are the levels of vitamin D, pain, functional status and quality of life in OA patients?

Is there a relationship between vitamin D levels and pain, functional status and quality of life in patients with osteoathritis?

\section{MATERIAL AND METHOD}

This study was conducted as a descriptive and cross-sectional. The study was carried out between April 15 and August 30, 2019, at the Orthopedics Clinic of a Research and Practice Hospital. The population of the research consisted of all patients with osteoarthritis who applied to the hospital between the specified dates. The research was completed with 138 individuals who met the inclusion criteria. At the end of the study power analysis ( $G *$ Power (v3.1.7) was performed using in order to determine the sample size. Considering VAS activity value with vitamin D obtained, the power of the study was found to be $82 \%$ at alpha $=0.05$. Inclusion criteria were (a) being diagnosed diagnosed with osteoarthritis for at least 6 months (b) being aged 18 years and older (c) being diagnosed with gonarthrosis (d) not having any problem that restricted daily life activities (e) being examined for vitamin D level (g) volunteering to participate in the research. Exclusion criteria were (a) being used drugs acting on the central nervous system (b) having a cancer diagnosis (c) being used vitamin $\mathrm{D}$, calcium, parathyroid hormone, and antiresorptive drugs in the last year.

\section{Data Collection}

The research data were collected using the Identification Form, VAS, WOMAC and SF-36- Quality of Life scale were used. The data was collected through face to face interviews with the participants. Each interview lasted about 20-30 minutes.

The Identification form was prepared by the researchers by investigating the literature and consists of 16 questions regarding patients' socio-demographic variables, information about the disease. ${ }^{[6,15,16]}$

The Visual Analogue Scale (VAS) scale is used to determine pain severity. The most severe pain is score "10" points and the absence of pain is scored " 0 ". The most intense pain the individual feels is marked on the scale. ${ }^{[17]}$ In this study, the severity of pain was questioned separately at activity and resting periods.

Turkish validity and reliability study of the WOMAC Osteoarthritis Index (WOMAC) was performed by Tüzün, Eker, and Aytar (2005) in 72 patients (Cronbach's alpha between 0.75-0.96). ${ }^{[18]}$ The index consists of 24 questions and three subscales. In the Likert-type index, the pain subscale is rated between 0-20; stiffness is rated between 0-8 for; the subscale of difficulties experienced during daily activities is rated 0-68. The highest score indicates an increase in pain and stiffness, a deterioration in physical function, and the highest level of physical limitation. ${ }^{[17,19]}$ Cronbach's a values for the WOMAC pain, stiffness, and physical function subdimensions in our study were $0.95,0.94$, and 0.97

SF-36 is used scales for measuring the quality of life. It was developed (1992) by Ware et al. ${ }^{[20]}$ and the Turkish validity and reliability study was conducted by Kocyigit et al. (Cronbach's alpha between 0.73-0.76). ${ }^{[21]}$ The scale consists of 36 items and these items enable the measurement of 8 dimensions. The subscales evaluate health between 0 (poor health) and 100 (good health). ${ }^{[21]}$ In our study Cronbach's alpha were found to range between 0.62 and 0.93 . 
Vitamin D levels of the patients were examined under appropriate conditions and in the same laboratory. VDD was defined as $<20 \mathrm{ng} / \mathrm{mL}$. $^{[22-25]}$ No additional vitamin $D$ examination was conducted for the study. The patient, who was deemed appropriate for vitamin $D$ by the physician, was reported after the examination. A questionnaire was applied to that patient. When the vitamin D result came out, the result was saved from the system.

\begin{tabular}{|c|c|c|}
\hline Characteristics & $\mathbf{n}$ & $\%$ \\
\hline \multicolumn{3}{|l|}{ Gender } \\
\hline Female & 106 & 76.8 \\
\hline Male & 32 & 23.2 \\
\hline \multicolumn{3}{|l|}{ Marital status } \\
\hline Married & 123 & 89.1 \\
\hline Single & 15 & 10.9 \\
\hline \multicolumn{3}{|l|}{ Place of residence } \\
\hline Province & 56 & 40.6 \\
\hline District & 41 & 29.7 \\
\hline Village & 41 & 29.7 \\
\hline \multicolumn{3}{|l|}{ Educational status } \\
\hline Illiterate & 40 & 29.0 \\
\hline Primary school & 69 & 50.0 \\
\hline Secondary school & 18 & 13.0 \\
\hline High school and over & 11 & 8.0 \\
\hline \multicolumn{3}{|l|}{ Income status } \\
\hline Income less than expenses & 40 & 29.0 \\
\hline Income equal to expenses & 92 & 66.7 \\
\hline Income more than expenses & 6 & 4.3 \\
\hline \multicolumn{3}{|l|}{ Family type } \\
\hline Nuclear & 112 & 81.2 \\
\hline Extended & 26 & 18.8 \\
\hline \multicolumn{3}{|c|}{ Presence of other chronic diseases* } \\
\hline Yes & 45 & 32.6 \\
\hline No & 93 & 67.4 \\
\hline \multicolumn{3}{|l|}{ Joint deformity } \\
\hline Yes & 36 & 26.1 \\
\hline No & 102 & 73.9 \\
\hline \multicolumn{3}{|c|}{ Use of osteoarthritis-related drugs } \\
\hline Yes & 119 & 86.2 \\
\hline No & 19 & 13.8 \\
\hline \multicolumn{3}{|c|}{ Status of receiving training on osteoarthritis and its care } \\
\hline Yes & 25 & 18.1 \\
\hline No & 113 & 81.9 \\
\hline \multicolumn{3}{|l|}{ Vitamin D (ng/ml) } \\
\hline Vitamin $\mathrm{D}<20$ & 89 & 64.5 \\
\hline Vitamin $D \geq 20$ & 49 & 35.5 \\
\hline Mean age (year) & \multicolumn{2}{|c|}{$59.00 \pm 11.66(45-89)$} \\
\hline Mean disease duration (year) & \multicolumn{2}{|c|}{$5.38 \pm 4.15(1-15)$} \\
\hline Mean treatment duration (year) & \multicolumn{2}{|c|}{$3.90 \pm 3.37(1-15)$} \\
\hline Mean vitamin D level (ng/ml) & \multicolumn{2}{|c|}{$16.37 \pm 8.33(3-39)$} \\
\hline
\end{tabular}

\section{Statistical Analysis}

The research data were evaluated in SPSS 21.0 package program in a computer environment. The KolmogorovSmirnov test and Shapiro-Wilk test were used to assess normally distributed data. Research findings were obtained by arithmetic mean, standard deviation and student's t-test. ${ }^{[26]}$ The statistical significance of the results was evaluated at $\mathrm{p}<0.05$.

\section{RESULTS}

It was found that $76.8 \%(n: 106)$ of the individuals with osteoarthritis were female; $89.1 \%$ ( $n: 123)$ were married. It was determined that $67.4 \%$ ( $n: 93)$ of the individuals had no other chronic disease; $73.9 \%$ (n:102) had no joint deformity; $86.2 \%$ (n:119) used drugs for osteoarthritis. $64.5 \%$ (n:89) of the individuals had a vitamin D level of $20 \mathrm{ng} / \mathrm{ml}$ and less. This finding demonstrates that most of the patients had VDD. The mean age of the individuals was $59.00 \pm 11.66$ years; the mean disease duration was $5.38 \pm 4.15$ years; the mean vitamin $D$ level was $16.37 \pm 8.83 \mathrm{~g} / \mathrm{ml}$ (Table 1 ).

The mean resting and activity VAS scores were $3.78 \pm 2.42$ and $5.94 \pm 2.26$, respectively. The mean WOMAC pain, stiffness and physical function were $10.57 \pm 5.54 ; 3.83 \pm 2.29$ and $33.33 \pm 14.55$ respectively. When the SF-36 mean subscale scores were examined, it was determined that the mean subscale score was $18.60 \pm 4.91$ for physical functioning, $5.29 \pm 1.45$ for rolephysical, $6.43 \pm 1.91$ for bodily pain, $13.48 \pm 4.17$ for general health, $12.52 \pm 4.24$ for Vitality (Energy), $5.54 \pm 1.72$ for social functioning, $4.12 \pm 1.07$ for role-emotional, and $20.91 \pm 4.59$ mental health (Table 2).

It was determined that there was no significant correlation between individuals' vitamin D levels and age, VAS (RestingActivity), WOMAC, and SF-36 subscales ( $p>0.05$ ) (Table 3 ).

Table 2. Distribution of the VAS, WOMAC, and SF-36 Quality of life scale subscale scores of the individuals with osteoarthritis

\begin{tabular}{lc} 
Scales & Mean \pm SD (Min-Max) \\
\hline VAS & \\
Resting & $3.78 \pm 2.42(0-10)$ \\
Activity & $5.94 \pm 2.26(1-10)$ \\
WOMAC & \\
Pain & $10.57 \pm 5.54(0-20)$ \\
Stiffness & $3.83 \pm 2.29(0-8)$ \\
Physical Function & $33.33 \pm 14.55(0-58)$ \\
SF-36 Subscales & \\
Physical Functioning & $18.60 \pm 4.91$ \\
Role-Physical & $5.29 \pm 1.45$ \\
Bodily Pain & $6.43 \pm 1.91$ \\
General Health & $13.48 \pm 4.17$ \\
Vitality (Energy) & $12.52 \pm 4.24$ \\
Social Functioning & $5.54 \pm 1.72$ \\
Role-Emotional & $4.12 \pm 1.07$ \\
Mental Health & $20.91 \pm 4.59$ \\
\hline Note: Visual analogue scale (VAS); WOMAC osteoarthritis index (WOMAC); \\
SF-36: Short Form 36; SD: Standard Deviation
\end{tabular}




\begin{tabular}{lccc}
$\begin{array}{l}\text { Table 3. Comparison of scale scores of individuals with osteoarthritis } \\
\text { according to their Vitamin D levels } \\
\text { Vitamin } \mathbf{D}<\mathbf{2 0} \\
\text { Ch:89) }\end{array}$ & $\begin{array}{c}\text { Vitamin } \mathbf{D} \geq \mathbf{2 0} \\
(\mathbf{n}: 49)\end{array}$ & $\mathbf{p}^{*}$ \\
\hline VAS Resting & $3.73 \pm 2.56$ & $3.87 \pm 2.15$ & 0.734 \\
VAS Activity & $6.01 \pm 2.30$ & $5.83 \pm 2.21$ & 0.667 \\
WOMAC Pain & $10.30 \pm 5.14$ & $11.24 \pm 4.86$ & 0.296 \\
WOMAC Stiffness & $3.609 \pm 2.30$ & $4.24 \pm 2.24$ & 0.118 \\
WOMACPhysical Function & $32.55 \pm 14.93$ & $34.75 \pm 13.87$ & 0.396 \\
SF-36 Subscales & & & \\
Physical Functioning & $18.76 \pm 4.79$ & $18.32 \pm 5.14$ & 0.618 \\
Role-Physical & $5.28 \pm 1.45$ & $5.32 \pm 1.46$ & 0.861 \\
Bodily Pain & $6.40 \pm 1.93$ & $6.50 \pm 1.89$ & 0.782 \\
General Health & $13.48 \pm 4.36$ & $13.48 \pm 3.84$ & 0.993 \\
Vitality (Energy) & $12.43 \pm 4.41$ & $12.69 \pm 3.95$ & 0.736 \\
Social Functioning & $5.57 \pm 1.75$ & $5.48 \pm 16.8$ & 0.787 \\
Role-Emotional & $4.19 \pm 1.18$ & $4.06 \pm 1.04$ & 0.523 \\
Mental Health & $20.96 \pm 4.58$ & $20.8 \pm 14.65$ & 0.855 \\
\hline Note: *Student test used. & & & \\
\hline
\end{tabular}

\section{DISCUSSION}

Vitamin $D$ has recently found focus due to its widespread effects on the musculoskeletal system. Also, the prevalence of VDD has consistently been on the rise. ${ }^{[2]]}$ In our research, most of the patients were found to have VDD. Likewise, Hekimsoy et al. was found that $74.9 \%$ had vitamin D deficiency. ${ }^{[27]}$ Our study finding is similar to the literature.

In our research, it was determined that there was no significant correlation between vitamin D levels of the patients and VAS and WOMAC subscales. However, the studies was found that vitamin $D$ had a protective effect against cartilage defect progression and Vitamin $D$ deficiency seems to be a factor contributing to pain, muscle weakness, and disability. ${ }^{[28,29]}$ Similar to our study, in the studies conducted no correlation were found between vitamin D levels and osteoarthritis. ${ }^{[7,8,30]}$ In a systematic review published in 2017, the effect of the use of vitamin $\mathrm{D}$ on the treatment of knee osteoarthritis was mainly focused on the pain parameter and it was reported that it did not affect pain.$^{[31]}$ The association between the concentration of vitamin $\mathrm{D}$ and $\mathrm{OA}$ is controversial. These findings determined in our study indicate that randomized controlled studies with larger sample size should be performed.

Vitamin D deficiency have been linked to poor quality of life. [9,32] In particular, pain and functional impairmentsare the primary burden of patients with $\mathrm{OA}$, and taken together, they often cause a significant decrease in quality of life. According to evidence-based knee osteoarthritis treatment recommendations of the Turkish League Against Rheumatism, the first goal of the OA treatment is to control the pain, maintain and improve joint functions, provide functional independence, and improve the quality of life. ${ }^{[33]}$ It was determined that there was no significant correlation between vitamin D levels and SF-36 subscales. In the study conducted by Dhesi et al., it was found that there was no significant improvement in any of the subscales of quality of life in the vitamin D loaded group. ${ }^{[34]}$ In the study conducted by Alkan et al. (2012), no significant correlation was found between initial vitamin D levels and quality of life. ${ }^{[15]}$ It is suggested that quality of life should be evaluated frequently by health professionals and that the quality of life should be improved by prioritizing the symptom control.

The limitations of the study include the lack of repetitive vitamin D measurements, the lack of monitoring patients after they received vitamin $D$ supplements, the evaluation of instant status, the ignorance of the current changes in normal life of patients while only considering the severity of the disease during the examination of osteoarthritis, which has a complex structure. This is considered among the uncontrollable factors of the research.

\section{CONCLUSION}

VDD is very common in OA. Vitamin D was no correlation between pain, functional status and quality of life of patients. Health professionals may apply practices regarding the prevention of VDD in patients with osteoarthritis to prevent symptoms of the disease. We recommend that these patients be regularly evaluated for VDD. Long-term studies are needed to evaluate the effects of vitamin D.

\section{ETHICAL DECLARATIONS}

Ethics Committee Approval: The study was carried out with the permission of Bozok University Faculty of Medicine Non-Invasive Trial Ethics Committee (Decision Number:2017KAEK-189_2019.04.24_14).

Informed Consent: All patients signed the free and informed consent form.

Referee Evaluation Process: Externally peer-reviewed.

Conflict of Interest Statement: The authors have no conflicts of interest to declare.

Financial Disclosure: The authors declared that this study has received no financial support.

Author Contributions: All of the authors declare that they have all participated in the design, execution, and analysis of the paper, and that they have approved the final version.

\section{REFERENCES}

1. Vos $\mathrm{T}$, Allen $\mathrm{C}$, Arora $\mathrm{M}$ et al. Global, regional, and national incidence, prevalence, and years lived with disability for 310 diseases and injuries, 1990-2015: a systematic analysis for the global burden of disease study 2015. Lancet 2016;388:1545-602.

2. Ovayolu N, Ovayolu Ö. editors. Basic internal medicine nursing and chronic diseases with different dimensions. Çukurova Nobel Yayınevi: Adana; 2016.

3. Ling SM, Rudolph K. Osteoarthritis, In: Clinical treatment in rheumatic diseases (3.Baskı), Dinç A. (Edt.), Özgün Ofset: Ankara; 2007.p.127-32.

4. Arslan DE, Kutlutürkan S, Korkmaz M. The effect of aromatherapy massage on knee pain and functional status in participants with osteoarthritis. Pain Manag Nurs 2019;20:62-9. 
5. Çalışkan N. Superficial hot and cold application in the treatment of knee osteoarthritis: are the evidences enough? J Contemp Med 2013;3:136-43.

6. Cakar M. Association between vitamin D concentrations and knee pain in patients with osteoarthritis. Peer J 2018;6:e4670.

7. Park CY. Vitamin $D$ in the prevention and treatment of osteoarthritis: from clinical interventions to cellular evidence. Nutrients 2019;11(2):243.

8. McAlindon $T$, LaValley $M$, Schneider $E$ et al. Effect of vitamin $D$ supplementation on progression of knee pain and cartilage volume loss in patients with symptomatic osteoarthritis: A randomized controlled trial. J Am Med Assoc 2013;309:155162

9. Jin $X$, Antony $B$, Wang $X$ et al. Effect of vitamin $D$ supplementation on pain and physical function in patients with knee osteoarthritis (OA): An OA Trial Bank protocol for a systematic review and individual patient data (IPD) meta-analysis. BMJ Open 2020;10(4):e035302.

10. Zhang FF, Driban JB, Lo GH et al. Vitamin D deficiency is associated with progression of knee osteoarthritis. J Nutr 2014;144:2002-8.

11. Yu Y, Liu D, Feng D, Zhao J. Association between vitamin D and knee osteoarthritis: a PRISMA-compliant meta-analysis. Zeitschrift für Orthopädie und Unfallchirurgie 2020.

12. Macfarlane GJ, Palmer B, Roy D, Afzal C, Silman AJ, O'Neill T. An excess of widespread pain among South Asians: are low levels of vitamin $D$ implicated? Ann Rheum Dis 2005;64: 1217-9.

13. Anand S, Kaysen GA, Chertow GM et al. Vitamin D deficiency, self-reported physical activity and health-related quality of life: the comprehensive dialysis study. Nephrol Dial Transplant 2011;1-6.

14. Huang W, Shah S, Long Q, Crankshaw AK, Tangpricha V. Improvement of pain, sleep, and quality of life in chronic pain patients with vitamin $D$ supplementation. Clin J Pain 2013;29:341-347.

15. Alkan S, Sarsan A, Alkan H, Yıldız N, Topuz O, Ardıç F. Relationshıp between balance, physical performance and quality of life with vtamin d levels in the elderly. Turkish J Geriatr 2012;15: 156-163.

16. Kim HJ, Lee JY, Kim TJ, Lee JW. Association between serum vitamin D status and health-related quality of life (HRQOL) in an older Korean population with radiographic knee osteoarthritis: data from the Korean national health and nutrition examination survey (2010-2011). Health Quality Life Outcomes 2015;13: 4.

17. Gallagher EJ, Liebman M, Bijur PE. Prospective validation of clinically important changes in pain severity measured on a visual analog scale. Ann Emerg Med 38:633-8.

18. Tüzün EH, Eker L, Aytar A. Acceptability, reliability, validity and responsiveness of the Turkish version of WOMAC osteoarthritis index. Osteoarthritis Cartilage 2001;13:28-33.

19. Aungst F, Aeschlimann A, Steiner W, Stucki G. Responsiveness of the WOMAC osteoarthritis index as compared with the SF-36 in patients with osteoarthritis of the legs undergoing a comprehensive rehabilitation intervention. Ann Rheum Dis 2001;60:834-840.

20. Ware JE, Sheurborune CD. The MOS 36-item short-form health survey (SF36). Med Care 1992;30:473-83.

21. Koçyiğit H, Aydemir Ö, Fişek G, Ölmez N. Reliability and validity of the Turkish version of short form-36 (SF-36) Drug and Therapy Journal 1999;12:102-6.

22. Çimen Atalar A. The Relationship Between $25(\mathrm{OH})$ Vitamin d level and the severity of disease and sleep quality in restless legs syndrome. Turk J Neurol 2019;25:87-91.

23. Fern L, Olazabal RM, Tovar KC, Alban NP, Wilman MV, Vilca JLR. Serum levels of vitamin D in women treated at rheumatology services in Lima Int. J Clin Rheumatol 2019;14:105-112.

24. Goula T, Kouskoukis A, Drosos G et al. Vitamin D status in patients with knee or hip osteoarthritis in a Mediterranean country. J Orthop Traumatol 2015;16:35-39.

25. Tu L, Zheng S, Cicuttini $F$ et al. Effects of vitamin D supplementation on disabling foot pain in patients with symptomatic knee osteoarthritis. Arthritis Care Res 2020. doi: 10.1002/acr.24371

26. Aksakoğlu G. Research and analysis in health. world of medical education 2006; 21:22-6.
27. Hekimsoy, Zeliha, et al. Vitamin D status among adults in the Aegean region of Turkey. BMC Public Health 2010;10(1):782.

28. Anari H, Enteshari-Moghaddam A, Abdolzadeh Y. Association between serum vitamin D deficiency and knee osteoarthritis. Mediterr J Rheumatol 2019;30(4):216-9.

29. Alkan SE, Çakıt BD, Salbaş E, Hakan G. The effects of vitamin d on muscle strength and functional status of the elderly patients with knee osteoarthritis. Aegean J Med Sci 2020; 3(2): 46-53.

30. Heidari B, Babaei M. Therapeutic and preventive potential of vitamin d supplementation in knee osteoarthritis. ACR Open Rheumatology 2019; 1(5):318-26.

31. Hussain S, Singh A, Akhtar M, Najmi, AK. Vitamin d supplementation for the management of knee osteoarthritis: A systematic review of randomized controlled trials. Rheumatology international 2017;37(9): 1489-98.

32. Alsowai S, Bin Bakr Z. Vitamin-d deficiency and insufficiency and quality of life in Jeddah, KSA: Is there any evidence of association. J Public Health Epidemiol 2018;10:62-8.

33. Tuncer T, Çay HF, Kaçar C et al. Evidence-based recommendations for the management of knee osteoarthritis: a consensus report of the Turkish league against rheumatism. Turk J Rheumatol 2012;(27):1-17.

34. Dhesi JK, Jackson SH, Bearne LM, et al. Vitamin D supplementation improves neuromuscular function in older people who fall. Age Ageing 2014;33:589-95. 